\title{
VALUATION OF TREE AESTHETICS ON SMALL URBAN-INTERFACE PROPERTIES
}

\author{
by Richard Thompson', Richard Hanna ${ }^{2}$, Jay Noel ${ }^{3}$, and Douglas Piirto ${ }^{4}$
}

\begin{abstract}
A model was developed to predict the value contribution of forest condition on small urban-wildland interface properties. Sample data were collected on property transactions in the Lake Tahoe Basin of California between 1990 and 1994. A variant of the stand density index (SDI) and a tree health measure were added to a list of traditional property characteristics (i.e., location, house size, lot size) to express the influence of tree care on property value. These aesthetic characteristics were statistically significant despite the expected dominant influence of the traditional characteristics. Values for the forest density and health characteristics were estimated and reveal a contribution to property value between $5 \%$ and $20 \%$.
\end{abstract}

Key Words. Urban-wildland interface; thinning; hedonic valuation; forest aesthetics.

A multitude of stresses and demands threaten the sustainability of America's private forest lands. As the keynote speaker to the Summit on Sustaining America's Forests put it, "America's private forests are being rapidly altered by urbanization, fragmentation, and forest health problems" (Sampson 1999). Many forest health problems arise indirectly from urbanizing wildlands, such as the need to suppress fire-a key ecosystem function. Landowners need information and economic incentives to invest in practices that will restore and maintain forest health in these urbanizing forested landscapes.

Residential woodland property owners are often unaware of how a healthy, attractive forest could add to their total property value. The purpose of this research was to identify and quantify the contributions that forest characteristics can have on woodland residential property value using observations from the Lake Tahoe Basin.

Urban forestry research has focused on the wide spectrum of benefits that trees provide to residential properties, such as wildlife habitat, energy and water savings, pollution reduction, and value-enhancing aesthetics (USDA 1990). Numerous studies have been conducted on the value of trees in urban and suburban settings; these studies used traditional appraisal methods such as those by the Council of Tree and
Landscape Appraisers (1992), Chadwick (1980), and Anderson and Cordell (1985). Other researchers have applied similar methods to valuation of rural wooded landscapes (Colorado State Forest Service 1979; Standiford et al. 1986; Magill 1989). Further studies have investigated the range of stocking and its impact on the condition of the forest (Ritters et al, 1990). Relatively little research has been done on the valuation of urban interface forest characteristics of the complete property (Garrod and Willis 1992).

The Shade Tree (Trunk) Formula (CTLA 1992), though very useful, is not well suited for valuation of practices designed to enhance stand health and amenity values on small urban interface acreages. This formula focuses more on valuation of an individual tree with no explicit consideration given to overall stand conditions. Therefore, a more classical valuation method, such as the hedonic model, is needed. The hedonic model developed follows most closely the works of Garrod and Willis (1992) and Jordan et al. (1985). The contribution of this research resides in the strength and proposed applicability of the empirical model.

The basic idea of the hedonic approach is to determine the contribution made by the characteristics of a good to its market price. Interest naturally focuses on the nonmarketable characteristics. In the hedonic model, a property's value is a function of the values of all the characteristics of that property, some of which are common to many properties and some of which are unique. Many, if not most, of a property's characteristics cannot be separated from the property. Hence, one must purchase a property to obtain a characteristic such as the house, a view, or aesthetics on the property itself, such as trees (Garrod and Willis 1992).

\section{LAKE TAHOE BASIN-AN IDEAL LABORATORY}

The Lake Tahoe Basin (LTB) lies on the border between California and Nevada and includes 84,240 ha $(208,000 \mathrm{ac})$ of land, of which approximately 44,550 
ha $(110,000 \mathrm{ac})$ are privately owned and 39,690 ha $(97,400 \mathrm{ac})$ are publicly owned. The LTB forest types are roughly divided by the state border, with the Nevada side containing the "east-side" pine type, which varies between pure stands of Jeffrey pine (Pinus jeffreyi) and a variety of associations in which Jeffrey pine is the majority. The California side consists mainly of the Sierra Nevada mixed-conifer type (i.e., California white fir [Abies concolor], ponderosa pine [Pinus ponderosa], sugar pine [Pinus lambertiana], incensecedar [Libocedrus decurrens], California black oak [Quercus kelloggii], and Douglas-fir [Pseudotsuga menziesii]).

The aesthetic created from the current LTB forested environment can be characterized as very unattractive and unhealthy due to human-caused overstocking and resultant disease and insect epidemics (Harcourt 1994). Fire exclusion is the primary cause of the abnormally dense forest. Added to these unnatural conditions was a 10-year drought that further stressed the forest, especially the white fir. The result is massive disease and insect infestation exacerbating the already high drought-induced tree mortality (Figure 1).

Under natural conditions, fire would have thinned these stands and provided natural regeneration. However, a century of urbanization has forced

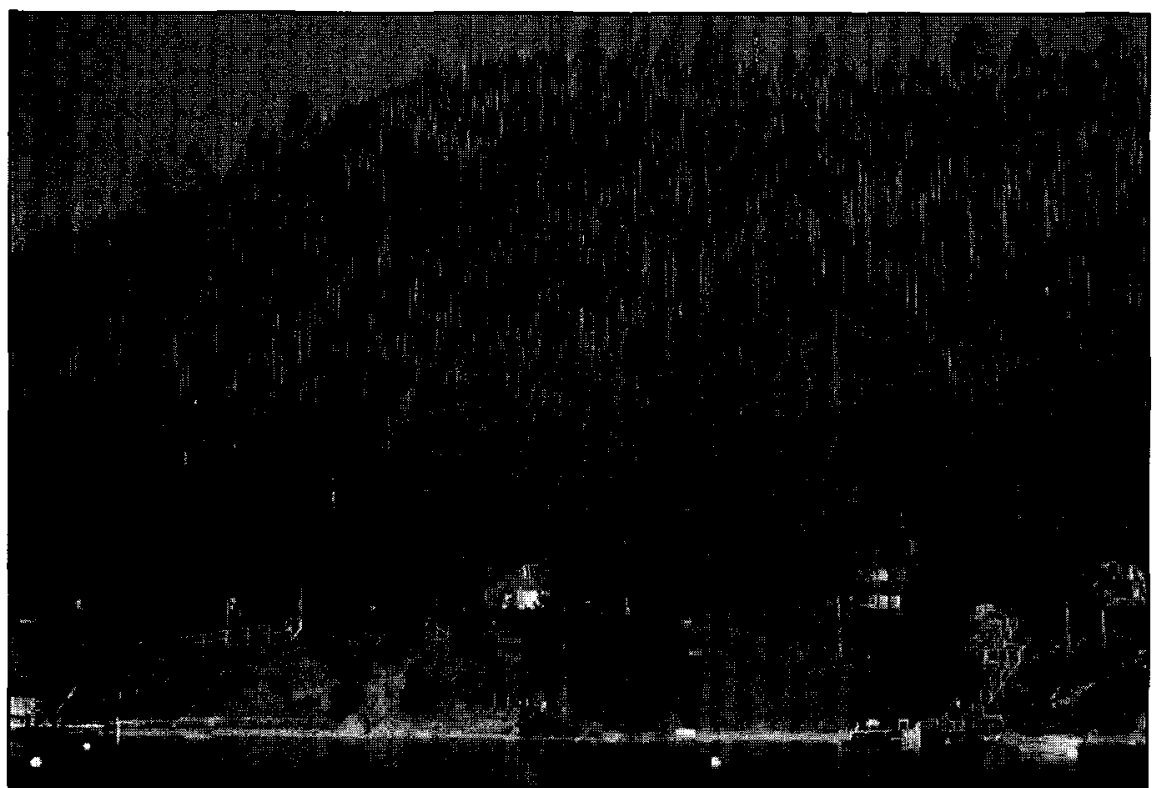

Figure 1. Property values in the Lake Tahoe Basin are jeopardized by the high tree mortality on private and public lands. exclusion of fire, halting nature's corrective processes. High rates of mortality and diseased survivors have dramatically affected the aesthetic of the LTB and therefore may be linked to the selling price of residential property. Tree removal (thinning) and other treatments could help rectify many of the current problems within the LTB and may be supported if economic returns can be demonstrated, but these treatments must be proactive rather than reactive to save property value.

To convince property owners to invest in preventive treatments usually requires "selling" the owner on the expected benefits of enhancing stand health and aesthetics. These aesthetics are generally fairly obvious in the LTB, where residential market values are clearly driven by views and property appearance.

\section{METHODS}

A general expression for the theoretical hedonic model follows:

$$
\mathrm{p}=\mathbf{H}^{\prime} \mathbf{X}+v .
$$

Here, the $\mathbf{X}$ vector represents the observable and quantifiable characteristics of the property, and $p$ is the market price of the property. Thus, the extent to which the market price varies in response to varying levels of $\mathrm{X}_{\mathrm{i}}$ expresses its implicit or hedonic price vector $\left(\mathrm{H}^{\prime}\right.$, the transpose of $\mathrm{H}_{\mathrm{i}}$ coefficients for each $\mathrm{X}_{\mathrm{i}}$ ). The theoretical error term (v) reflects not only error in market data but also property uniqueness.

We hypothesized that the traditional housing valuation characteristics (e.g., location, size of the home, size of the property, views from the property), along with forest aesthetic characteristics, would account for a property's price (Witte et al. 1979). The following functional expression of equation (1) identifies the property characteristics to empirically estimate property price (PRICE): 


$$
\begin{aligned}
& \text { PRICE } \left.=h_{1} \text { (location or view }\right)+h_{2} \text { (house size) } \\
& \left.+h_{3} \text { (acres) }+h_{4} \text { (Trees }\right)+\varepsilon
\end{aligned}
$$

where Trees is an instrumental variable for a vector of forest aesthetic characteristics, and $\varepsilon$ is the observed error term.

Individual variables must be defined for the Trees forest aesthetics instrumental vector. We hypothesized that variables of tree size, number of trees per acre, condition, and species would significantly influence forest property values. Diameter of the tree of average stand basal area (DBH) and trees per acre (TPA) are fundamental variables in describing stand density and, in turn, its aesthetic influence on PRICE. These are typical stand measures and have a well-established methodology in data collection that promotes usefulness. However, as the stand ages, TPA and DBH relate inversely in their contribution to stand density. Therefore, measures that integrate TPA and DBH could be substituted for these variables in Trees. We chose Stand Density Index (SDI) because of its wide acceptability (Reineke 1933). SDI is commonly defined as

$$
\mathrm{SDI}=\mathrm{TPA}\left[\frac{10}{\bar{d}_{q}}\right] \beta
$$

where TPA is trees per acre, $\bar{d}_{q}$ is stand quadratic average diameter of TPA, and $\beta$ is Reineke's slope coefficient relating TPA to $\bar{d}_{q}$, approximately -1.6 for many North American tree species (Clutter et al. 1983).

Nonlinearities between SDI and PRICE made it necessary to allow the relationships between TPA, $\mathrm{DBH}$, and PRICE to vary. Therefore, we use a different variable to express the value influence from $\mathrm{SDI}$ (SDIVAL):

$$
\text { SDIVAL }=\operatorname{TPA}^{\varphi}\left[\frac{10}{\mathrm{DBH}}\right] \gamma
$$

where $\varphi$ and $\gamma$ are ex post estimable value-related TPA and DBH coefficients, respectively.

Further variables are needed to express the degree of infection in trees, INFECT, and forest type, NS. The result is the final empirical expression to be modeled:

$$
\begin{aligned}
& \text { PRICE }=\mathrm{H}_{1}(\mathrm{SQFT})+\mathrm{H}_{2}(\mathrm{ACRES})+\mathrm{H}_{3}\left(\mathrm{VIEW}^{2}\right) \\
& +\mathbf{H}_{4}(\mathrm{INFECT})+\mathrm{H}_{5}(\mathrm{SDIVAL})+\varepsilon
\end{aligned}
$$

where both of the SDIVAL parameters, $\varphi$ and $\gamma$, equal 1.5 .

\section{Sample Data}

Sample data were collected on the characteristics of property transactions from the California side of the LTB during summer 1994 (Hanna 1994). The sample was designed by randomly selecting 100 transactions from more than 300 small $(0.1$ to 2 ha [0.3 to $5 \mathrm{ac}]$ ) property transactions between 1989 and 1994, stratified into four price strata in accordance with recommendations from local real estate agents. Although price data were collected in 1994 for home sales over a 5-year period, no accommodation for trends in prices was deemed necessary due to the brevity of the time-series and confirmation from real estate agents that the housing market was essentially flat during this period. On-site observations and verifications were made of all property characteristics deemed relevant based on interviews with agents and property purchasers (refer to appendix for data descriptions). Exploratory analysis was conducted using the full range of variables in an attempt to identify collinearities and means of designing instrumental variables to save degrees of freedom. The result was the set of variables, described in Table 1, to be used in the final empirical model. The sample size was reduced to 76 transactions because some characteristics or prices of sample properties were unverifiable.

For each property, tree groupings were identified and sampled to characterize forested structure, composition, and condition. A single 0.081 ha $(0.2 \mathrm{ac})$ plot was established for each plant grouping, and data were collected (see appendix for specific data).

For each property, plant groupings were identified and sampled to characterize forested structure, composition, and condition. Variables constituting the Trees vector (DBH, TPA, INFECT) were created by averaging plant grouping variables weighted by area.

\section{RESULTS}

Using the quadratic form of the Box-Cox transformation to address nonlinearities, an autoregressive model produced very impressive results (Table 2). The forest type variable, NS, was used as the crosssectional stratum in Shazam's POOL procedure 
(White 1978). The results demonstrate a very good fit of the model $180 \%$ of the variation in price accounted for by the model).

Evaluating these coefficients (using Equation [3]) at the mean of all variables except SDIVAL permits interpretation of the value influence of SDI constituent terms, TPA and DBH. Figure 2 illustrates the property value effect of TPA for a given DBH. That is, it would require a greater TPA at lower DBHs to influence price than for larger DBHs.
Table 1. Data definitions.

\begin{tabular}{|c|c|c|}
\hline Variable & Definition & Scale \\
\hline PRICE & Sale price of sample property & $\$$ (verified) \\
\hline ACRES & Acreage of property sale & Listed \\
\hline SQFT & Square footage of heated living area & Listed \\
\hline NEAR-VIEW & $\begin{array}{l}\text { View as seen of adjacent property and surroundings } \\
\text { (see appendix Table A1) }\end{array}$ & $1-10$ \\
\hline FAR-VIEW & $\begin{array}{l}\text { Panoramic view as seen from the property } \\
\text { (see appendix Table A2) }\end{array}$ & $1-10$ \\
\hline VIEW & $(2 *$ Near View + Far View $) / 3$ & $1-10$ \\
\hline NS & A proxy for forest type $(1=$ Placer Co., $2=$ Dorado Co. $)$ & $1-2$ \\
\hline DBH & $\begin{array}{l}\text { Area weighted average of average dbh by plant group } \\
\quad(0.81 \text {-ha or } 1 / 5 \text {-ac plots) plots) (see appendix Table A3) }\end{array}$ & Inches \\
\hline TPA & $\begin{array}{l}\text { Area weighted average of average TPA plant grouping } \\
\quad(1 / 5-a c \text { plots) (see appendix Table A3) }\end{array}$ & \# per ac \\
\hline INFECT & $\begin{array}{l}\text { Area weighted average of average infection rating } \\
\text { by plant group (see Appendix Table A3) }\end{array}$ & $1-4$ \\
\hline
\end{tabular}

Note: A plant group is defined in this study as a somewhat homogeneous association of overstory and understory plants that is further delineated by its orientation to views to and from the house.
Movement along one of these curves indicates the substitution between TPA and DBH while maintaining a constant SDIVAL. Removing the smaller trees, "thinning from below," can immediately increase the average $\mathrm{DBH}$, as illustrated by the dashed line in Figure 2 . In addition, such thinning improves the view from and of the home while promoting vigorous growth of the residual trees.

Our results suggest that by thinning an overly dense stand of trees to enhance the residential forested character, the owner can add value to the property. The property shown in Figure 3 is a typical example. Here, high stand density and trees clearly detract from aesthetic value and pose a serious fire hazard.

Removing diseased trees, trees too close to houses, and some of the younger and smaller trees improves views and reduces fire hazards (Figure 4). These improvements should bring a significant increase in property values, according to our results.

The following equation was used to predict the price of 10 observed properties selected to represent the price and size ranges of the total sample:

\section{Predicted Price $=$}

$e^{\left(11.591+.0002(\mathrm{SQFT})+.19488(\mathrm{ACRES})+.00477\left(\mathrm{VIEW}^{2}\right)-.08704(\mathrm{INFECT})+.00014(\mathrm{SDIVAL})\right)}$
Table 2, Results of hedonic generalized least square models of PRICE.

\begin{tabular}{lll}
$\begin{array}{l}\text { Variables and } \\
\text { statistics }\end{array}$ & $\begin{array}{l}\text { GLS coefficients } \\
(\mid \mathrm{t}-\mathrm{valuel})\end{array}$ & $\begin{array}{l}\text { Hedonic price } \\
(\$ / \text { increment })\end{array}$ \\
\hline SQFT & $0.0002(3.32)^{*}$ & $\$ 64 / \mathrm{ft}^{2}$ \\
ACRES & $0.19488(3.11)^{*}$ & $\$ 60,066 / \mathrm{ac}$ \\
VIEW2 & $0.00477(7.43)^{*}$ & $\$ 3,482 /$ unit \\
INFECT & $-0.08704(2.77)^{*}$ & $-\$ 26,390 /$ unit \\
SDIVAL & $0.00014(2.78)^{*}$ & $\$ 9,071 / 100$ \\
Constant & $11.591(73.55)^{*}$ & $\$ 334,009^{2}$ \\
\hline F-value & 56.006 & \\
Buse Ry & 0.800 & \\
Log L.F & -8.409 & \\
df & 70 & \\
\hline
\end{tabular}

${ }^{2}$ Grand mean property price was $\$ 334,009$; median property price was $\$ 219,500$. Hedonic prices were calculated as increments from the grand mean property price.

"Because of the aesthetic nature of this characteristic, it is possible to create an intervally scaled variable despite efforts to the contrary. Thus, interpretation of the coefficient and hedonic price as an incremental contribution to PRICE cannot be made. ${ }^{*}$ indicates that the 2 -tailed $\mathbf{t}$-value of the coefficient is significant at the 0.01 level. 


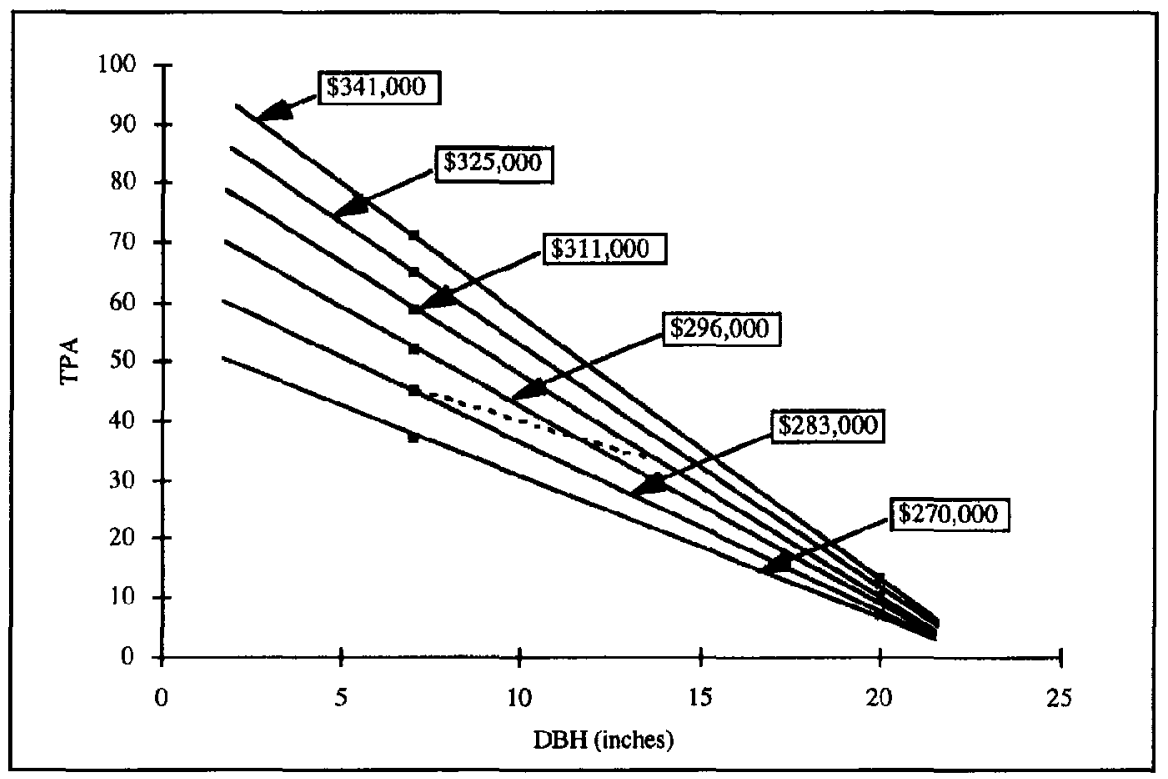

Figure 2. Equal SDIVAL curves between DBH and TPA, evaluated at the mean for all other variables. Dashed line reflects the value effect of a sanitation thinning.

The price effect was estimated for a generic $40 \%$ TPA "thinning from below" prescription that would increase average stand DBH by about $7.6 \mathrm{~cm}$ ( 3 in.) (Table 3). Each of these properties usually has many dozens of trees, which factor is overstated by the TPA value for smaller properties.

The thinning prescription alone was estimated to add from $1 \%$ to $3 \%$ to the value of these properties. There did not appear to be any correlation between size or price and the magnitude of the thinning enhancement. If the thinned trees were those most heavily infected (reducing their INFECT value to 1.0 ), then property values could be enhanced an additional 5\% and as much as $30 \%$ on properties with many infected trees.

These estimates are consistent with value estimates for residential trees in the Guide for Plant Appraisal (stating 7\% to $15 \%$ percent from uncited studies). Because these thinnings are also designed to promote fire safety, it is reasonable
Table 3. Predicted value increases from thinning trees and removing infected trees on 10 selected observations across the range of property prices and sizes. could be called "high end," but we do not believe this lessens the relevance of the results. In fact, it merely helped accentuate the value contribution of forest aesthetics above the statistical "noise" in these markets.

Stand density and health measures seemed to serve well as proxies for forest aesthetics, especially when used in a more composite or integrative way (e.g., SDI). However, it is possible that the property value enhancements from improved densities and to attribute part of the value enhancements to reduction in fire risk. Such thinning intensity on these size properties provides a sufficient number of trees and volume for owners to reasonably expect some costoffsetting revenues, given that these interface areas often have active wood markets.

\section{CONCLUSIONS}

that the forested character of a property can be valued with a degree of confidence in the methodology equal to that which would be required to estimate marketable values. Cer-

\begin{tabular}{|c|c|c|c|c|c|c|c|c|}
\hline SQFT & ACRES & VIEW & TPA & $\mathrm{DBH}$ & INFECI & $\begin{array}{l}\text { Predicted } \\
\text { price } \\
\text { (PPrice) }\end{array}$ & $\begin{array}{l}\text { PPrice w/ } \\
40 \% \text { thin }\end{array}$ & $\begin{array}{l}\text { PPrice w/ } \\
40 \% \text { thin \& } \\
\text { INFECT }=1\end{array}$ \\
\hline 1025 & 0.36 & 1 & 126 & 4.5 & 2.5 & $\$ 118,100$ & $\$ 121,000$ & $\$ 137,900$ \\
\hline 1152 & 0.35 & 1.67 & 82 & 6.2 & 4 & $\$ 107,300$ & $\$ 109,000$ & $\$ 141,500$ \\
\hline 1104 & 0.47 & 1 & 100 & 8.4 & 3 & $\$ 124,600$ & $\$ 125,750$ & $\$ 149,600$ \\
\hline 1224 & 0.3 & 2 & 66 & 3.1 & 1.5 & $\$ 131,200$ & $\$ 132,500$ & $\$ 138,400$ \\
\hline 1800 & 0.38 & 5.67 & 86 & 7.8 & 3 & $\$ 158,400$ & $\$ 160,000$ & $\$ 192,000$ \\
\hline 1310 & 0.5 & 1 & 183 & 7.7 & 3.5 & $\$ 137,300$ & $\$ 139,200$ & $\$ 173,000$ \\
\hline 1560 & 2.07 & 4 & 86 & 6.5 & 2.5 & $\$ 198,900$ & $\$ 201,300$ & $\$ 229,400$ \\
\hline 2765 & 0.48 & 5 & 66 & 4.6 & 1 & $\$ 214,400$ & $\$ 216,500$ & $\$ 216,500$ \\
\hline 3261 & 1.1 & 6 & 181 & 7.1 & 3 & $\$ 269,300$ & $\$ 276,000$ & $\$ 328,400$ \\
\hline 3123 & 1.6 & 1 & 105 & 4.1 & 1 & $\$ 298,700$ & $\$ 408,000$ & $\$ 408,000$ \\
\hline
\end{tabular}




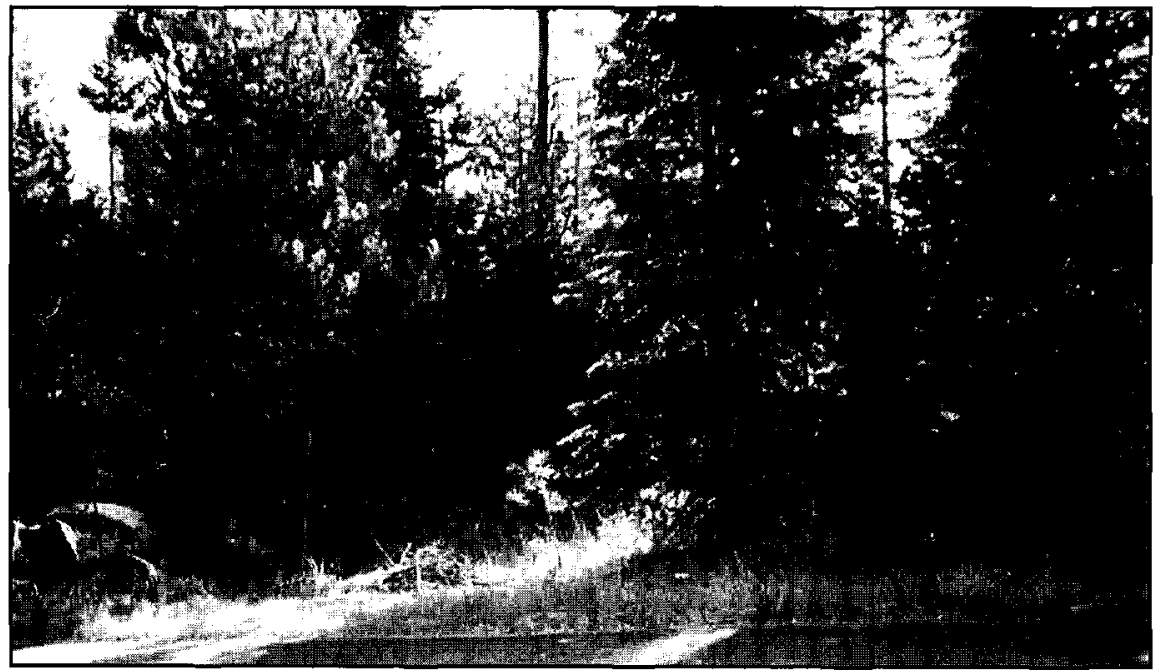

this, or any, fire-prone region uses fire protection landscaping as a determinant of the cost of coverage. Properties treated to resist wildfire should receive a reduced premium, just as nonsmokers receive lower-cost life insurance. Further study into the insurance dimension is needed, as is involvement with, and education of, the insurance industry to stimulate investment in tree care.

Figure 3. A typical LTB property in need of arboricultural treatment.

health do not arise solely from the aesthetic effects. Fire risk in the Lake Tahoe Basin, like many urban interface areas in the U.S. west, has become widely recognized by residents recently, and markets may reflect the benefits of reduced fire risk from managed improvements. Such benefits, however, are inherently jointly produced from proper tree and stand care.

Our results should lend support for current efforts to encourage investment in tree and stand care on small forest acreages in the urban interface where wood commodity values are negligible. Tangible benefits from expenditures on improving forest aesthetics can be presented to landowners. Benefits not directly reflected in our estimated values include community landscape benefits, the many social intangibles, and potential revenues from thinned wood material to offset treatment costs. Another unrecognized benefit for landowners is the potential reduction in the cost of, or even likelihood of obtaining, fire insurance. To our knowledge, no insurer in

\section{LITERATURE CITED}

Anderson, L., and H. Cordell. 1985. Residential property values improved by land-scaping with trees. South. J. Appl. For. 9(3):163-166.

Chadwick, L.C. 1980. Review of guide for establishing values of trees and other plants. J. Aboric. 6(2):48-50.

Clutter, J.L. J.C. Fortson, L.V. Pienaar, G.H. Brister, and R.L. Bailey, 1983. Timber Management: A Quantitative Approach. Wiley, New York, NY.

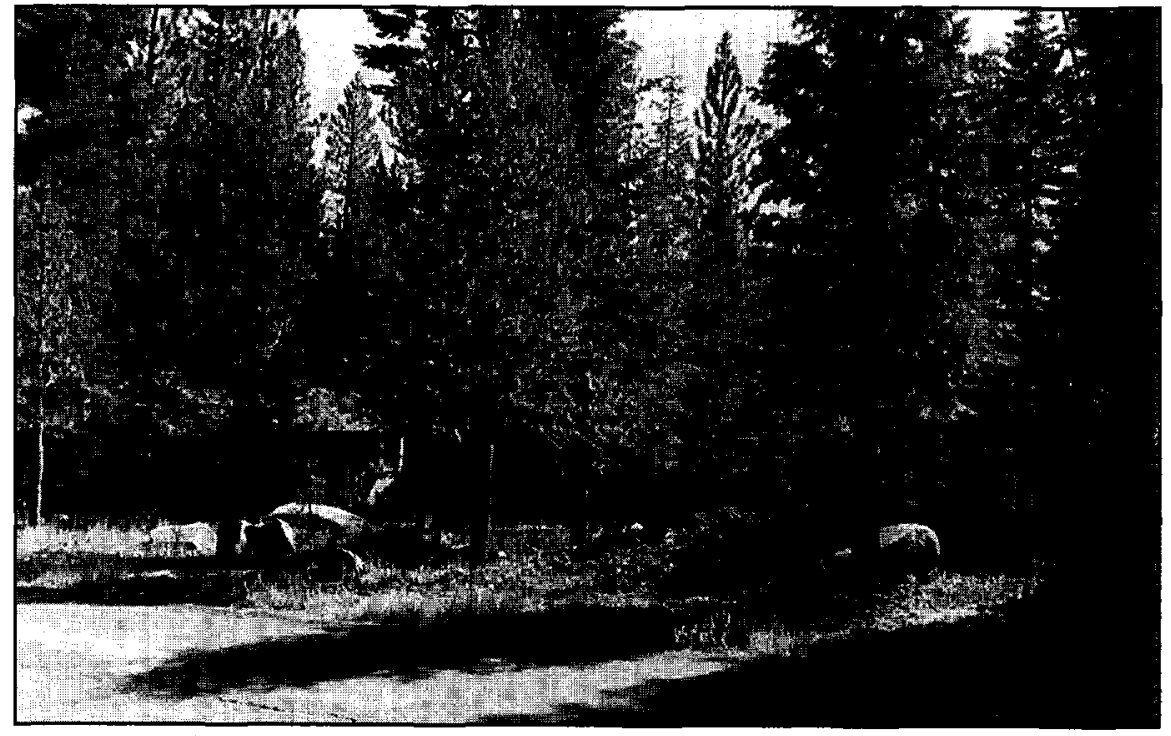

Figure 4. The same property in Figure 3 after prescribed value-enhancing thinning (similar view angle). 
Colorado State Forest Service/Colorado State University. 1979. Dollars and Sense About Your Trees. Colorado State Forest Service, Ft. Collins, CO.

Council of Tree and Landscape Appraisers. 1992. Guide for Plant Appraisal (8th ed.). International Society of Arboriculture. Champaign, IL, $103 \mathrm{pp}$.

Garrod, G.D., and K.G. Willis. 1992. Valuing goods' characteristics: An application of the hedonic price method to environmental attributes. J. Environ. Manage. 34(1):59-61.

Hanna, R.J. 1994. Economic contribution of forest attributes to property value in the Lake Tahoe basin of California. M.Sc. thesis, California Polytechnic State Univ., San Luis Obispo, CA. 117 pp.

Harcourt, S. 1994. Personal communication. California Department of Forestry and Fire Protection, Tahoe/ Eastside.

Jordan, J., R. Shewfelt, S. Prussia, and W. Hurst. 1985. Estimating implicit marginal prices of quality characteristics of tomatoes. South. J. Agric. Econ. 17(2):139-146.

Magill, A.W. 1989. Searching for the Value of a View. USDA For. Serv., PSW. 27 pp.

Reineke, L.H. 1933. Perfecting a stand density index for even-age forests. J. Agric. Res. 46:627-638.

Ritters, K., B. Law, R. Kucera, A. Gallant, R. de Velice, and C. Palmer. 1990. Indicator strategy for forests in ecological indicators for the environmental monitoring and assessment program, pp 6-1-6-13. In Hunsaker, C.T. and D.E. Carpenter (Eds.). US EPA, EPA 600/3-90606. Office of Research and Development, Research Triangle Park, NC.

Sampson, R.N. 1999. Keynote address at the NAPFSC/ CSREES Summit on Sustaining America's Forests: The Role of Research, Education and Extension. Washington, DC, 22 Feb. 1999.

Standiford, R., N. Diamond, P.C. Passof, and J. LeBlanc. 1986. Value of oaks in rural subdivisions, pp 156-160. In Proceedings of Multiple-Use Management of California's Hardwood Resources. San Luis Obispo, CA.

United States Department of Agriculture. 1990. Forest Resource Value and Benefit Measure: Some Cross Cultural Perspectives. USDA For. Serv. RM, Washington, DC.

White, K.J. 1978. A general computer program for econometric methods-Shazam. Econometrica 46:239240.

Witte, A., H. Sumka., and H. Erekson. 1979. An estimate of a structural hedonic price model of the housing market: An application of Rosen's theory of implicit markets. Econometrica 47(5):1151-1173.
${ }^{1 *}$ Professor, Natural Resources Management

Department and Director, Urban Forest

Ecosystem Institute

California Polytechnic State University

San Luis Obispo, CA 93407

${ }^{2}$ Project Manager, Spieker Properties

Emeryville, CA

${ }^{3}$ Professor, Agribusiness Department

California Polytechnic State University

San Luis Obispo, CA

${ }^{4}$ Professor, Natural Resources Management

Department

California Polytechnic State University

San Luis Obispo, CA

\section{*Corresponding author}

\section{APPENDIX}

\section{Table A1. Near viewshed rating guide.}

1 = NO VIEW, possibly along major road or heavy-use area

2 = VERY POOR, surrounding property heavily overstocked, and in poor condition

$3=$ POOR, characteristics of (1) and (2) but in a modest degree

$4=$ BORDERLINE, more (3) attributes than (5)

$5=$ FAIR, on side of overgrown or undermanaged

$6=$ INDETERMINATE, mild effort to manage condition

$7=$ IMPROVING, more (6) attributes than (8)

$8=$ GOOD, possibly hilltop and well-stocked forest adjacent

$9=$ VERY GOOD, near lake with wide view or open space

$10=$ EXCELLENT, surrounding property is possibly lakefront or parklike forest service land adjacent

\section{Table A2. Far viewshed rating guide.}

$1=$ NO VIEW, possibly along major road or heavy-use area

2 = VERY POOR, surrounding property heavily overstocked and in poor condition

$3=$ POOR, characteristics of (1) and (2) but in a modest degree

$4=$ BORDERLINE, more (3) attributes than (5)

$5=$ FAIR, on side of overgrown or undermanaged

$6=$ INDETERMINATE, on side of mild, or effort to manage

7 = UNENCUMBERED, more (6) attributes than (8)

$8=$ GOOD, possibly hilltop and well-stocked forest in the distance

$9=$ VERY GOOD, near lake with wide views of mountains or open space

$10=$ EXCELLENT, outlying property is possibly lakefront or views of mountain ranges in the distance and/or ski slopes 
Table A3. Hazard rating guide.

Assessment

Penalty

A. Needle Condition

Needle Complements

Needle complement normal

0

Less than normal complement through crown $\quad 0.5$

No contrast between upper and lower crown $\quad 0.5$

Thin complement in upper crown, normal in lower crown; contrast evident 1

Needle Length

Needle length normal

Needle length shorter than normal. No contrast between upper and lower crown $\quad 0.5$

Needle short on top and normal below; marked contrast 1

Needle Color

Normal

0

Off-color

0.5

Fading over entire tree

8

B. Twig and Branch Condition

No twigs or branches dead

0

A few scattered dead or dying twigs or branches in live crown $\quad 0.5$

Many scattered dead or dying twigs or branches in live crown 1

Dead or dying branches forming a hole in top one-third of live crown 2

\section{Top Crown Condition}

No top killing

Old top kill, green below $\quad 0.5$

Old top kill, weakness below 2

Current top killing more than one-half of live crown 6

Broken top recent less than one-third of live crown 1

Broken top recent more than one-third of live crown 2

$\begin{array}{ll}\text { Broken top old, no progressive weakness } & 0.5\end{array}$

D. Trunk and Root Conditions

Mistletoe on main stem, swelling evident 2

Active Dendroctonus valens 2

Active Ips or Scolytus

Stem cankers less than $50 \%$ of circumference $\quad 2$

Stem cankers $50-70 \%$ of circumference 4

Stem cankers over $70 \%$ of circumference $\quad 8$

Butt and Stem Mechanical or Fire Damage Scars

$5-15 \%$ of stem and bark circumference gone 1

$16-30 \%$ of stem and bark circumference gone 3

$31 \%$ or more of stem and bark circumference gone 5

Fungus Visible

$5-15 \%$ of stem basal area affected 3

$16 \%$ or more of stem basal area affected 5 
Table A3. Hazard rating guide (continued).

Assessment

D. Trunk and Root Conditions (continued)

\section{Other Stem Rots}

Pines

No fruiting bodies

0

One fruiting body

2

Two or more fruiting bodies

Fir

No fruiting bodies

One or more fruiting bodies

Root Rots

None present

One or more

Root Damage from Construction

$0-15 \%$

$16-30 \%$

$31 \%$ or more

E. Leaning Trees

Less than $3 \%$ off of vertical

$3-5 \%$ off of vertical

Over $5 \%$ off of vertical

Total penalty scores from categories A, B, C, D, and E added to determine risk class.

\begin{tabular}{ll} 
Penalty Score & Infect Scale \\
0 & 1 \\
$1-4.5$ & 2 \\
$5-7.5$ & 3 \\
8 and higher & 4 (dead trees would receive a maximum score) \\
\hline
\end{tabular}


Résumé. Un modèle a été développé pour prédire la valeur contributive immobilière de la condition de la forêt sur de petites propriétés situées dans la zone d'interface urbaine-rurale. Des données d'échantillonnage ont été recueillies à partir de transactions sur des propriétés dans le bassin du lac Tahoe en Californie entre 1990 et 1994. Une variante de l'index de densité du peuplement et une mesure de la santé des arbres ont été ajoutées à la liste des caractéristiques traditionnelles de la propriété-c'est-à-dire localisation, maison et dimension du terrain-afin d'exprimer l'influence de l'état des arbres sur la valeur de la propriété. Ces caractéristiques esthétiques étaient statistiquement significatives malgré l'influence dominante anticipée des caractéristiques traditionnelles. Des valeurs selon la densité de la forêt et les caractéristiques de santé ont été estimées et ont révélé une valeur immobilière contributive entre 10 et $20 \%$.

Zusammenfassung. Es wurde ein Modell entwickelt, um den Beitrag des Waldbestandes zum Grundstückswert bei kleinen Grundstücken vorherzusagen. Die Auswertungsdaten wurden bei Grundstückstransaktionen in der Region von Lake Tahoe, Kalifornien, zwischen 1990 und 1994 gesammelt. Eine Variante des Indexes zur Standortdichte (SDI) und eine Bewertung der Baumgesundheit wurde einer Liste von traditionellen Grundstückseigen- schaften (z.B. Standort, Haus, Größe, etc.) zugefügt, um den Einfluß von Baumpflege auf den Grundstückswert auszudrücken. Diese ästhetischen Charakteristika waren statistisch signifikant, ungeachtet des erwarteten vorherrschenden Einflusses auf die traditionellen Charakteristika. Der Wert der Walddichte und der Baumgesundheit wurde bewertet und ergab einen Einfluß auf den Grundstückswert von 10 bis $20 \%$.

Resumen. Se desarrolló un modelo para predecir la contribución de la condición de un bosque al valor de la propiedad en pequeñas propiedades de interfase urbanorural. Los datos de la muestra fueron colectados con base en transacciones de propiedades en la cuenca del lago Tahoe de California entre 1990 y 1994. Se agregó una variante del indice de densidad del rodal (SDI) y una medida de la salud del árbol, a la lista de las características tradicionales de la propiedad (por ejemplo, ubicación, tamaño del predio y de la casa) para expresar la influencia del cuidado del árbol sobre el valor de la propiedad. Estas características estéticas fueron estadísticamente significativas a pesar de la influencia dominante esperada de las características tradicionales. Fueron estimados los valores para la densidad del bosque y características de salud, y revelan una contribución al valor de la propiedad entre un 10 y un 20 por ciento. 